\title{
THE ESSENCE AND SIGNIFICANCE OF INFORMATION TECHNOLOGY IN MANAGING THE COSTS
}

\author{
(C)Abipova G., SPIN-code: 3002-0530, ORCID: 0000-0002-2325-0008, \\ Uzbek State institute of Art and Culture, Nukus, Uzbekistan, abipova86@mail.ru \\ СУЩНОСТЬ И ЗНАЧЕНИЕ ИНФОРМАЦИОННЫХ ТЕХНОЛОГИЙ \\ В УПРАВЛЕНИИ ЗАТРАТАМИ
}

\begin{abstract}
(C)Абипова Г. C., SPIN-код: 3002-0530, ORCID: 0000-0002-2325-0008, Государственный институт искусства и культуры Узбекистана, 2. Нукус, Узбекистан, abipova86@mail.ru
\end{abstract}

Abstract. The article provides the value and content of the information management system in the business cost management system. At the same time, the opinions of scientists on the management of information supply are analyzed and the author's conclusions are drawn.

Аннотащия. В статье представлена стоимость и содержание системы управления информацией в системе управления затратами на бизнес. В то же время анализируются мнения ученых об управлении информационным обеспечением и сделаны выводы автора.

Keywords: cost, management, information, technology, business, joint-stock companies.

Ключевые слова: стоимость, управление, информация, технология, бизнес, акционерные общества.

In the conditions of modernization of the economy, the effectiveness of management in jointstock companies can be achieved through the timely use of external sources of information and practical implementation of up-to-date news. To this end, adaptation to the modernization of the economy depends on the equity of stock companies to meet the modern information requirements. The reason is that modern information systems will reduce workloads, reduce workloads, speed up work, avoid excessive paper waste and innovate new ideas in management.

The First President's comments on the importance of providing information in managerial activities can be summarized as follows: "Today, our lives are unmatched by computer techniques, information technology, the Internet" [1].

E. L. Shuremov, D. V. Chistov, G. V. Lyamova's textbooks say that "The most effective way to manage the business is to collect and analyze all of the information that business impacts on business and organization of business", explaining the importance of information management in enterprise management [2].

In the scientific works of Russian scientists V. Amelin and I. A. Synkov, it has been called "a complex of economic information and behavioural trends that characterize the processes of supply control, the purpose of the processes of their management, and the processes of their management" [3].

H. S. Zaynutdinov and Sh. N. Zaynutdinov in their textbook commented on the significance of information support in the management process as "The main objective of the communication process is to provide the understanding of information, which is a means of communication, which 
is necessary for a certain level of interaction between the organization's head and its subordinates" [4].

T. J. Jiemuratov noted in his research that "optimal information provision is not only a guarantee of enterprise success and competitiveness but sometimes it is also a means of keeping face-to-face under strict competition conditions" [5].

B. B. Begalov proposed the concept of formation of the information and communication market in the conditions of the formation of an information society in the face, methods of econometric modelling and trends of their development [6].

M. N. Kambarov offered a comprehensive and systematic study of the management process for the effective organization and development of information and communication technologies in their face-to-face research [7].

Increasing the efficiency of expense management is largely related to the rational organization of information, mainly due to the incorrect classification of information, the reliability, the speed of information, the availability of information in the database.

The information can be divided into two different and non-extrabudgetary sources. Internal and external audits, auditors' conclusions, and tax audit results can be included in the accounting, tax and operational reporting, non-accounting sources of information.

According to the information, the most important source of management costs is the accounting of the enterprise. The only source that has been systematized for this mood is to be prepared primarily in simple, standard, sophisticated or cramped edges.

Practice shows that operating companies with a complex manufacturing system are in great need of operational economic information that helps them optimize costs and financial results in managing decision-making.

The information needed for the operational management of enterprise costs is contained in the management accounting system, which is one of the new and prospective directions of accounting practice.

The lack of information and the lack of quality of information facilitates the effective management of business costs. It leads to considerable losses in the current modernization of the economy, in particular, the loss of competitiveness of the products manufactured, their sales, storage of goods in the warehouse, timely clearance of payments, non-payment of demand.

The management account is intended as a cost management tool to provide better methods for collecting and communicating costs based on the overall strategic development of the enterprise.

For the first time in the 20th century, the need for the formation of an information system on production costs was outlined in G. Emerson's book, "Workforce Generation Wages and Essentials of Work Efficiency". It first attempted to separate the report as an independent course of production costs [8].

Various concepts that explain the content of the management account and the use of information are available in economic literature.

According to S. Satubaldina, the management account describes the classification of expenditure, the type of activity on the types of products, the profit centre, the estimate, the type of activity that is involved with costs and their analysis [9].

According to V. V. Ivashkevich, the management account has denied that the management account combines all the cost analysis, accounting and planning into a single system [10].

Therefore, management information is structured in a way that depends on the user's needs. It has production accounting data on its database, which is necessary information for managers to make operative decisions in the field of production. 
The management account is intended to reflect the processes of past economic activities (through indicators) and perspectives (through forecasting).

Thus, the management account includes all kinds of reporting types such as accounting, operational accounting, and cost analysis for enterprise management.

During the study of the benefits of management accounting, it has been concluded that it serves the following:

-providing managers with the necessary information for future decision making and business management;

-calculate the true cost of the product and determine its estimate, standards, deviation from the defined values;

-identifying financial results for sales.

Thus, the main task of the management account is control-management and information support. They reflect the exact types of management accounts: information-controlling, information-forecasting, information analysis, information management. Gathering the necessary information for managing the decision making systematizes the content of the management account. This kind of information primarily includes cost information, product cost, product development and sales metrics.

The main part of managerial accounting costs management is to analyze the costs of the information provided by it and, with the adoption of decisions, puts the following tasks:

-registration of expenses on site and types;

-classification of expenditures;

-evaluating the cost of the product sold and the type of activity;

-price control;

-studying expenses, their composition and dynamics;

-preparing information for management decisions.

Instruments such as documentation, monitoring, appraisal, calculations, calculations, analysis and forecasting, reporting, and informatization of management accounts serve as the basis for tactical and strategic decision making.

In order to increase its effectiveness when working with economic information in a dynamic market environment, the information can be classified in the following way:

-shrinking (inside and outside);

-repeat (current and emergency);

-facility (enterprise, bulim, product);

-time (according to time, date).

The usefulness of information is characterized by the difference between their significance and costs. Therefore, the expansion of the information process is cost-effective, but not their cost. The usefulness of information can also be assessed through the discounting effect of the effectiveness of the achievement of the objective and the results achieved. The cost of the information includes salaries and material costs, ie the cost of searching, storing, processing, and disposing of information.

Thus, it is necessary to improve the management capacity in the volume, quality, timing, organizational and economic context.

Information systems of joint-stock companies should meet the following requirements:

-the flexibility of business activities of all forms of ownership;

-the user has the capacity to use the organization's economic, financial, and production performance; 
-integrity, that is, the targeted functionality of all systems means its compatibility with the system target functions;

-modularity, precise restriction of autonomous use and operational management issues in separate parts of the system during a single integrated database;

-functional and structural integrity of the system, ie production, economic functions.

Thus, understanding the position of the information support system in the business administration is illustrated in the picture below (Figure 1).

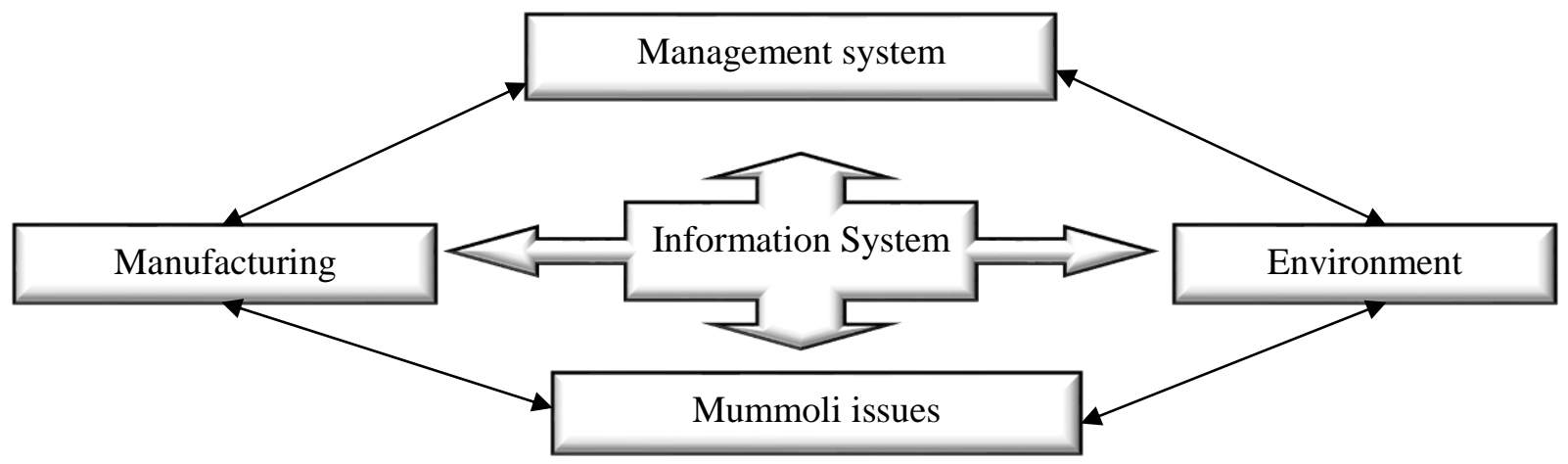

Figure 1. Relationship with the information environment to the environment (Designed by the author).

At all stages of the enterprise, there is a cost-management problem, which, in turn, is related to rapid economic changes. In such a situation, the company needs to keep its balance in balance and to achieve a high economic level, taking into account the micro-macroeconomic status of the business, and the quick and efficient use of available resources.

In order to effectively manage the costs of the enterprise in the conditions of modernization of the economy, it must create a system related to the implementation of all organizational and business plans of the organization, with the exception of the goals and objectives of cost management.

The expenditure management system represents a complex of recent achievements in theoretical and practical knowledge, which is based on the characteristics, functions and relationships of expenditure management, the processes that cover all levels, the structure of business activities, adaptation of the enterprise to real-life situations.

Effective functioning of the cost management system depends on many factors. One of the most important factors is the ability of managers to organize their work with information resources, including technical, personal, financial systems.

Management of information resources in the process of cost management may depend on:

-optimization and refinement of future, current and operational planning decisions on operating costs;

-forming the system for effective management of operating costs;

-establishment of normative, project and operating costs of operating costs;

-analyze cataracts at all stages of the production process and at all levels of management.

The aforementioned actions can be seen as a cost-management process for information management. Efficient and cost-effective management of expenses depends on the optimal organization of enterprise information. 
Effective implementation of information technology is provided only in situations where managers are explicitly aware of their capabilities, and also depends on their collection, registration, delivery, processing, storage, analysis and management decisions.

The abort system can be generalized as follows (Figure 2).

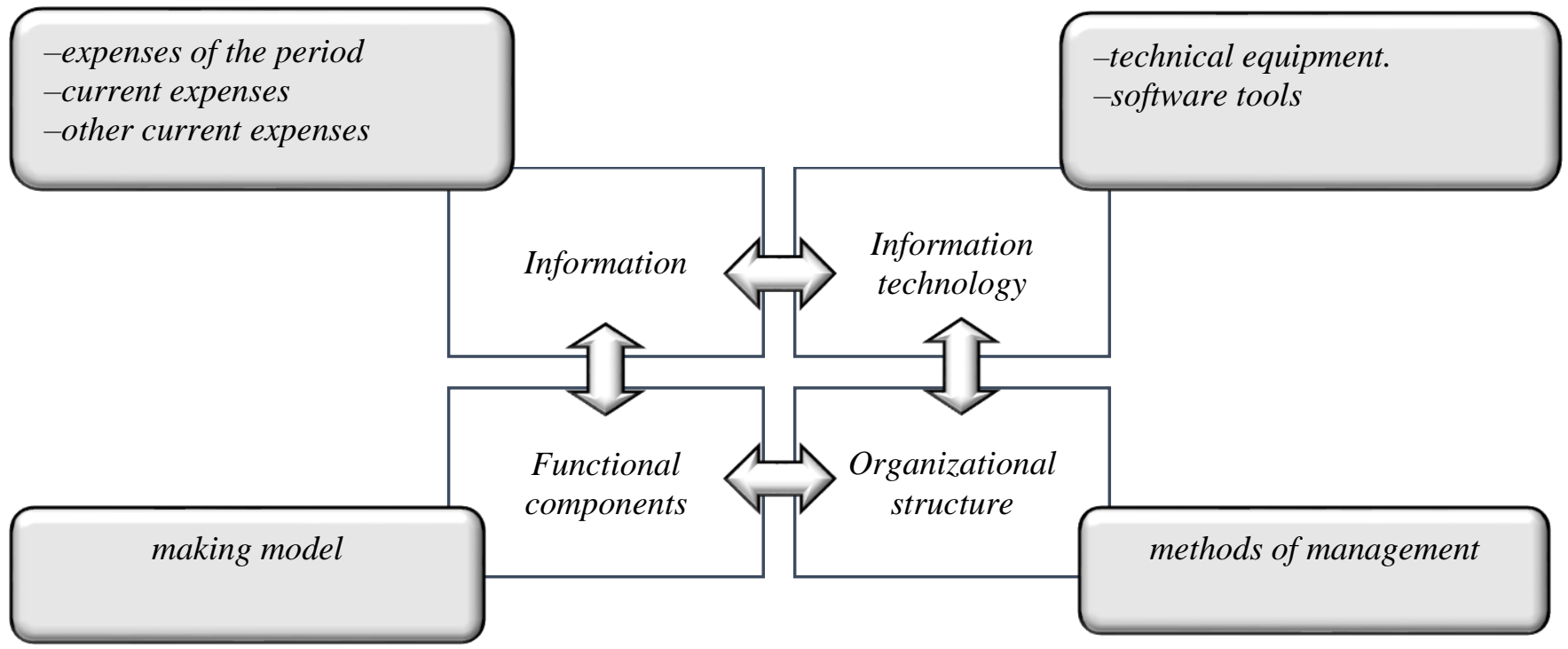

Figure 2. Information management system (Designed by the author).

Here, the information that is needed to make informed management decisions is characterized by a set of resources.

The following information can be placed on the management system:

-completeness of the information to carry out management activities;

-accuracy and reliability of information;

-data integrity;

-low cost and profitability;

-elasticity;

-relevance, timeliness and efficiency of information retrieval.

Information technology is a means of identifying methods and tools for collecting, storing, processing, and transmitting information in the information system. The technological process of information processing in the information system consists of separate operations, which include technical and software tools, and is a comprehensive automation tool for effective functioning management, that is, through the work of all departments of the enterprise.

The organizational unit of the management is the managing body and organizational structure that performs the management functions using the information technology information technologies.

The basis of the information system is the functional components, namely, models and algorithms that capture management information.

Functional structure - functional system subsystems, which carry out functions of the management system, tasks are a complex of information processing.

One of the key features of the expense management system is its dynamic, ie the need for information systems, with changes in the internal and external environment, which are characteristic of the objectives of the enterprise.

An effective functional cost management system should be focused on current and strategic business objectives and should address the following: 
-integrate cost management tools at different levels of business cost management;

-the use of new information technologies.

Thus, for the effective functioning of the cost management system, the information system should be provided with the following tools:

-provision of effective documentation;

-construction and operation of modern software;

-arranging the necessary maintenance.

All of the above will be necessary, which will create a complex of information that will help you to deal with issues of long and short duration. Effective information support is a necessary tool for cost management.

As it is known from the amate- ted, the companies need complex economic information to optimize the costs and financial outcomes of the production process and to make the management decisions. Low and insufficient information reduces the ability to manage business costs significantly. Under current conditions, these can lead to significant losses, reduced product competitiveness, loss of sales, and many other adverse effects.

Describing information as economic resources, economist scientist A. Sh. Kudaybergenov underlined that it is advantageous to use an automated communication system 1C:Enterprise in enterprise management [8]. This system is crucial for the establishment of the enterprise information base, but it is more appropriate to simplify the way it is used.

In the organization's cost management system, it tries to highlight the information support system that is capable of producing accurate and timely information on costs, as it is the only system that provides users with information about the results of their economic activity.

\section{References:}

1. Karimov, I. A. (2010). Our main task is to advance the development of our homeland and to improve the well-being of our people. Tashkent.

2. Shuremov, E. L., Zalozhnev, A. Yu., \& Chistov, D. V. (2008). Modeli i metody resheniya tipovykh zadach ekonomicheskogo analiza. Moscow, Bukhgalteriya i banki. 149. (in Russian).

3. Amelin, S. \& Synkov, I. (2011). Providing information on expenditure management. Innovative Technology Development, (3), 77. (in Russian).

4. Zaynutdinov, H. S., \& Zaynutdinov, Sh. N. (2009). Pharmaceutical management. Tashkent. 246.

5. Jiemuratov, T. P. (2010). Improving the organization of enterprise management processes information. Tashkent, 6 .

6. Begalov, B. A. (2004). Econometric modeling of formation and development of information and communication market. Tashkent.

7. Kambarov, M. N. (2004). Effective use of information and communication technologies in the banking system. Tashkent.

8. Emerson, G. (1911). 12 princes of productivity.

9. Satubaldina, S. (1980). Accounting for production costs in the US industry. Tutorial. Moscow.

10. Ivashkevich, V. B. (2011). Accounting management accounting. Moscow. (in Russian).

\section{Список литературы:}

1. Каримов И. А. Наша главная задача - продвигать развитие нашей родины и улучшение благосостояния наших людей. Ташкент, 2010. 
2. Шуремов Е. Л., Заложнев А. Ю., Чистов Д. В. Модели и методы решения типовых задач экономического анализа. М.: Бухгалтерия и банки, 2008. 149 с.

3. Амелин С., Сынков И. Предоставление информации об управлении расходами // Развитие инновационных технологий. 2011. №3. С. 77.

4. Зайнутдинов Х. С., Зайнутдинов Ш. Н. Фармацевтический менеджмент. Ташкент, 2009. C. 246.

5. Джемуратов Т. П. Совершенствование организации процессов управления информацией предприятия. Ташкент, 2010. С. 6.

6. Бегалов Б. А. Эконометрическое моделирование формирования и развития информационно-коммуникационного рынка. Ташкент, 2004.

7. Камбаров М. Н. Эффективное использование информационно-коммуникационных технологий в банковской системе. Ташкент, 2004.

8. Эмерсон Г. 12 принципов производительности. 1911.

9. Сатубалдина С. Учет себестоимости продукции в промышленности США. М., 1980.

10. Ивашкевич В. Б. Бухгалтерский управленческий учет. М., 2011.

Cite as (APA):

Abipova, G. (2019). The essence and significance of information technology in managing the costs. Bulletin of Science and Practice, 5(3), 292-298. https://doi.org/10.33619/2414-2948/40/34.

Ссылка для цитирования:

Abipova G. The essence and significance of information technology in managing the costs // Бюллетень науки и практики. 2019. Т. 5. №3. С. 292-298. https://doi.org/10.33619/2414$2948 / 40 / 34$. 